Dicle Tıp Dergisi / Dicle Med J (2019) 46 (3) : 461 - 469

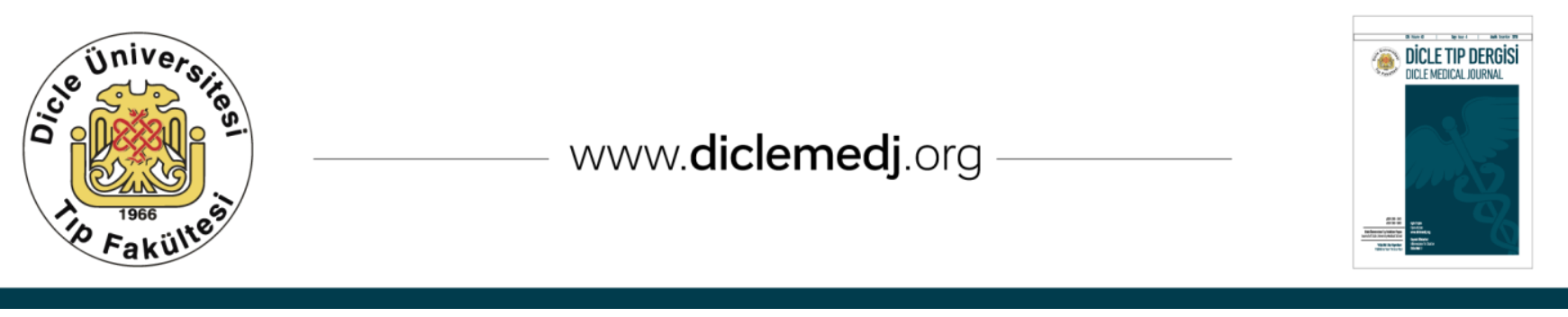

Özgün Araștırma / Original Article

\title{
Kardiyak cerrahi sonrası gelişen sağlık bakımı ile ilişkili enfeksiyonların değerlendirilmesi-tek merkez deneyimi
}

\author{
Zehra Çağla Karakoç¹ \\ 1 İstinye Üniversitesi Tıp Fakültesi, Enfeksiyon Hastalıkları ve Klinik Mikrobiyoloji İstanbul, Türkiye ORCID: 0000-0002-1618-740X
}

Geliş: 29.03.2019; Revizyon: 01.08.2019; Kabul Tarihi: 05.08.2019

Öz

Giriş: Son yıllarda artan aterosklerotik kalp hastalığı insidansı ile orantılı olarak, dünyada ve ülkemizde kardiyak cerrahi giderek artan sayıda hastaya uygulanmaktadır. Bu ameliyatlar sonrası gelișen sağlık bakımı ile ilișkili enfeksiyon (SBIEE)'lar ise ileri yaș ve komorbiditeleri olan bu hasta grubunda mortalitenin önemli bir nedenidir. Literatürde bu enfeksiyonların sıklığı \%2,25-24,9 arasında bildirilmektedir. Çalıșmamızda kardiyak cerrahi sonrası SBİE gelişen hastaların risk faktörlerinin, mikrobiyolojik özelliklerinin ve mortalite oranlarının retrospektif olarak değerlendirilmesi amaçlandı.

Yöntemler: Çalışmamıza Ocak 2013- Eylül 2018 tarihleri arasında açık kalp cerrahisi ameliyatı olan 744 erișkin hastada gelișen 36 SBİE dahil edildi. Olguların demografik bilgileri, olası SBİE risk faktörleri, etken mikroorganizmalar ve antibiyotik duyarlılıkları, mortaliteleri hastane kayıtları ve enfeksiyon kontrol komitesi sürveyans dosyalarından retrospektif olarak değerlendirildi. Üreyen bakteri türleri ve antibiyotik duyarlılıkları VITEK® 2 (bioMérieux, Marcyl'Etoile, Fransa) otomatize sistemi ile tanımlandı.

Bulgular: Ortalama SBİE hızı \%4,8 (36/744), cerrahi alan enfeksiyon (CAE) hızı \%2.9 (22/744) olarak saptandı. Enfeksiyon gelișen 32 hastanın 21'sine (\%65,6) koroner arter by-pass cerrahisi uygulandı.Olguların $23(\% 71,9)$ 'ü erkek, ortalama yaşları $62.2(38-80)$ olup, $22(\% 68,8)$ 'sinin ASA skoru $\geq 3$ idi. Ortalama vücut kitle indeksi 24,8, $11(\% 34,4)$ 'i obez hastalardan oluşmaktaydı. Yirmi yedi $(\% 84,3)$ hastada en az bir komorbidite vardı ve en sık komorbidite \%43,7 oranında diyabetti. Enfeksiyonların dağılımı sırası ile; \%61,1'i (CAE), \%24,9'u pnömoni, \%8,2'si kan dolaşımı enfeksiyonu, \%5,5'i idrar yolu enfeksiyonu idi. Etyolojiden sorumlu mikroorganizmalar \%77,8 $(28 / 36)$ enfeksiyonda izole edilebildi ve en baskın etken; \%55,6 (20/36) ile gram negatif mikroorganizmalar idi. Sağlık bakımı ile ilişkili enfeksiyon gelișenlerde\%28,1(9/32)oranında mortalite geliști.

DOI: 10.5798/dicletip.620481

Yazışma Adresi / Correspondence: Zehra Çağla Karakoç, İstinye Üniversitesi Tıp Fakültesi Topkapı Kampüsü, Maltepe mah. Edirne Çırpıcı Yolu, No:9 Zeytinburnu, İstanbul, 34010, 08502836000 e-mail: ckarakoc@gmail.com 
Sonuç: Çalışmamızda tek merkezin kalp ameliyatları sonrasında gelişen SBİE’larını paylaştık. SBİE'ların gelişimi açısından en temel risk faktörleri; ileri yaş, yüksek ASA (AmericanSociety of Anestesiology) skoru, diyabet, obezite, internalmammarian arter kullanımı, uzayan ameliyat süresi, intraoperatif kan ve kan ürünü kullanımı, postoperatifhiperglisemik seyir, uzayan mekanik ventilasyon süresidir. Literatürdeki büyük olgu volümlü çalışma sonuçları da bizim sonuçlarımızı desteklemektedir.

Anahtar kelimeler: kardiyak cerrahi, risk faktörleri, sağlık bakımı ile ilişkili enfeksiyon.

\title{
Evaluation of healthcare associated infections after cardiac surgery-single center experience
}

\begin{abstract}
Objective: In proportion to the increased incidence of atherosclerotic heart disease in recent years, cardiac surgery are being applied to an increasing number of patients. The healthcare associated infections (HAIs) after these operations are an important cause of mortality in these patients with advanced age and comorbidities. Reported incidence of these infections ranges from $2.25 \%$ to $24.9 \%$. Aim of this study was to evaluate the risk factors, microbiological characteristics and mortality rates of patients who developed HCAI after cardiac surgery retrospectively.

Method: The study included 36 HCAIs that developed in 744 adult patients who underwent open heart surgery between January 2013-September 2018. Demographic data of the patients, possible risk factors, etiologic microorganisms, antibiotic susceptibilities and mortality were evaluated retrospectively. Isolated bacteria and their antibiotic susceptibility were identified using VITEK® 2 system (bioMérieux, Marcy l'Etoile, France).

Results: The mean HAI rate was 4.8\% (36/744) and the rate of surgical site infection (SSI) was 2.9\% (22/744). Coronary artery bypass grafting was performed in $21(\% 65.6)$ of 32 patients. Twenty three $(71.9 \%)$ of the cases were male and the mean age was 62.2, $22(68.8 \%)$ had an ASA (American Society of Anestesiology) score of $\geq 3$. The mean body mass index was 24.8 and $11(34.4 \%)$ were obese patients. Twenty seven $(84.3 \%)$ patients had at least one comorbidity and the most common was $43.7 \%$ diabetes. Distribution of infections are; $61.1 \%$ SSI, $24.9 \%$ pneumonia, $8.2 \%$ bloodstream infection and 5.5\% urinary tract infection. Etiologic agent was identified in $77.8 \%$ of infections and $55.6 \%$ were gram-negative microorganisms. Mortality was $28.1 \%$ in patients who developed HAIs.

Conclusion: We shared the HAIs of a single center after cardiac surgery. The most important risk factors HAIs are; advanced age, high ASA score, diabetes, obesity, internal mammarian artery use, prolonged operation time, intraoperative erythrocyte use, post-operative hyperglycemia, prolonged mechanical ventilation which were similar in high volumestudies inliterature.
\end{abstract}

Keywords: cardiac surgery, risk factors, healthcare associated infections.

\section{GİRIŞ}

Kardiyak cerrahi sonrasında gelişen SBİE'lar da; uzayan hastane yatıșının, maliyet artışının ve mortalitenin önemli bir nedeni olarak karşımıza çımaktadır ${ }^{1}$. Literatürde bu enfeksiyonların sıklığı \%2,25-24,9 arasında bildirilmektedir ${ }^{1-7}$.Kalp ameliyatları sonrası, SBİE gelişme riskini artıran en önemli neden; kardiyopulmoner "by-pass" ve ekstrakorporeal dolaşıma bağlı artan stress faktörlerinin genel bir inflamatuvar yanıt olușturmasıdır. Bazı durumlarda bu inflamatuvar yanıtın abartılı bir durumda meydana gelmesi, sistemik inflamatuvar yanıt sendromuna ve çoklu organ disfonksiyonuna yol açabilmektedir. Ayrıca; birden fazla cerrahi insizyon bölgesinin bulunması, ameliyat süresinin uzunluğu, postoperatif dönemde invazif araçların sıklıkla kullanılması ve yine bu dönemde hastane personeli ile temasin fazla olması, inflamasyonenfeksiyon ayırımındaki klinik zorluklar nedeni ile bazen geniş endikasyonla antibiyotik kullanımı, ameliyat yapılan hasta grubunda ileri 
yaş, komorbidite ve kompleks cerrahi girişimlerin olması SBİE’ların artması ile ilgili diğer risk faktörleri olarak siralanabilir ${ }^{8}$. Bu risk faktörlerinin tanımlanması önleyici yaklaşımların geliştirilerek morbidite ve mortalitenin azalmasına büyük katkı sağlayacaktır.

Çalışmamızda kardiyak cerrahi sonrası SBİE gelişen hastaların risk faktörlerinin, mikrobiyolojik özelliklerinin ve mortalite oranlarının retrospektif olarak değerlendirilmesi ve literatüre katkı sağlanması amaçlandı.

\section{YÖNTEMLER}

Çalışmamıza Ocak 2013- Eylül 2018 tarihleri arasında İstinye Üniversitesi Tıp Fakültesi Ulus Hastanesinde açık kalp ameliyatı yapılan 744 erişkin (>18 yaş) hastada gelişen 36 SBİE dahil edildi. SBİE tanısı Amerika Hastalık Kontrol Merkezi (CDC) kriterlerine göre tanımlandı ${ }^{9}$.

Olguların demografik bilgileri, komorbiditeleri, yatış süreleri, nazal Staphyloccoccusaureus taşıyıcllı̆̆l, AmericanSociety of Anestesiology (ASA) skoru, vücut kitle indeksi (VKİ), acil girişim, internalmammarian arter (IMA) kullanımı, per-operatif kan ve kan ürünü kullanılması, ameliyat ve pompa süresi, cerrahi profilaksinin süresi, post-operatifhiperglisemik seyir ( $\geq 200 \mathrm{mg} / \mathrm{dl})$, kanamaya bağlı revizyon cerrahisi gereksinimi, intra-aortik balon pompası kullanımı, sternumun geç kapatılması, re-entübasyon, mekanik ventilasyonun 24 saatten uzun sürmesi, inme gelişmesi, renalreplasman tedavisi gereksinimi ve yoğun bakımda yatış süresi kaydedildi.

Ayrica SBíz'ların tanısl, etken mikroorganizmalar ve antibiyotik duyarlılıkları, yıllık kardiyak cerrahi sayıları, yapılan ameliyatların dağılımı, SBİE'nun belirlendiği tarih ve mortaliteleri hastane kayitları ve enfeksiyon kontrol komitesi sürveyans dosyalarından retrospektif olarak değerlendirildi.
Üreyen bakteri türleri ve antibiyotik duyarlılıkları VITEK ${ }^{\circledR} \quad 2$ (bioMérieux, Marcyl'Etoile, Fransa) otomatize sistemi ile tanımlandı. Üreyen mikroorganizmaların direnç tanımı; çoklu ilaç direnci (ÇíD); üç veya daha fazla antimikrobiyal kategori içinde en az bir antibiyotik direnci, genişletilmiş ilaç direnci (GID); bir veya iki kategoride duyarlık olmasına karşın diğer tüm antibiyotik kategorilerinde direnç ve tüm ilaçlara dirençli bakteri (TID) ise tüm antibiyotik kategorilerindeki tüm antibiyotiklere direnç olarak tanımland $1^{10}$.

Ameliyatlar, ilk yıl hariç diğer beş yıl boyunca aynı kardiyovasküler cerrahi ekip tarafından gerçekleştirildi. Enfeksiyon hastalıkları takibi tek ve aynı hekim tarafından yapıldı. Rutin cerrahi profilakside, tüm hastalara 1-2 gr sefazolinintravenöz olarak anestezi indüksiyonu ile beraber uygulandı. Tüm hastalar ameliyattan bir gece önce $\% 2$ klorheksidinglukuronat içeren solusyon ile duş aldı ve tüylerin temizliği elektrikli makine ile bir gece önce veya ameliyat sabahı yapıldı. Kapak replasmanı uygulanacak olan veya yabanci uyruklu hastalardan pre-operatif dönemde nasal S. aureus taşıyıcılığı için kültür alındı. Taşıyıcılık saptanan vakalara uygun oral antibiyotik ve klorheksidinglukoronat içeren sabun ile tüm vücut banyosu uygulandı ve bu yıkanmayı anlatan bir adet broşür verildi. Hastane enfeksiyon kontrol komitesi işleyiși gereği elde edilen surveyans verileri düzenli aralıklarla cerrahi ekip ile paylaşıldı.Hastalar servis izlemi sürecine kadar, altı yataklı kardiyovasküler cerrahi yoğun bakım ünitesinde takip edildi.

İstinye Üniversitesi Tıp Fakültesi Klinik Araştırmalar Etik Kurulundan 2019/3 sayılı onay alındı. İstatistiksel veriler SPSS (Statistical Package for Social Sciences) Windows 11.5 programı kullanılarak oluşturuldu. Tanımlayıcı analizler; sayısal değișkenler, ortalama, standart sapma, minimum ve maksimum değerler olarak, kategorik değişkenler ise; sıklık ve yüzde şeklinde gösterildi. 


\section{BULGULAR}

Altı yıllık sürede toplam 744 erişkin hastaya kardiyak cerrahi yapıldı ve bu hastaların 32'sinde 36 SBİE gelişti. Ortalama enfeksiyon hızı \%4,8 (36/744), cerrahi alan enfeksiyon (CAE) hızı \%2,9 (22/744) olarak saptandı. Enfeksiyon gelișen 32 hastanın 21'sine $(\% 65,6)$ koroner arter by-pass cerrahisi uygulandı (Şekil 1).

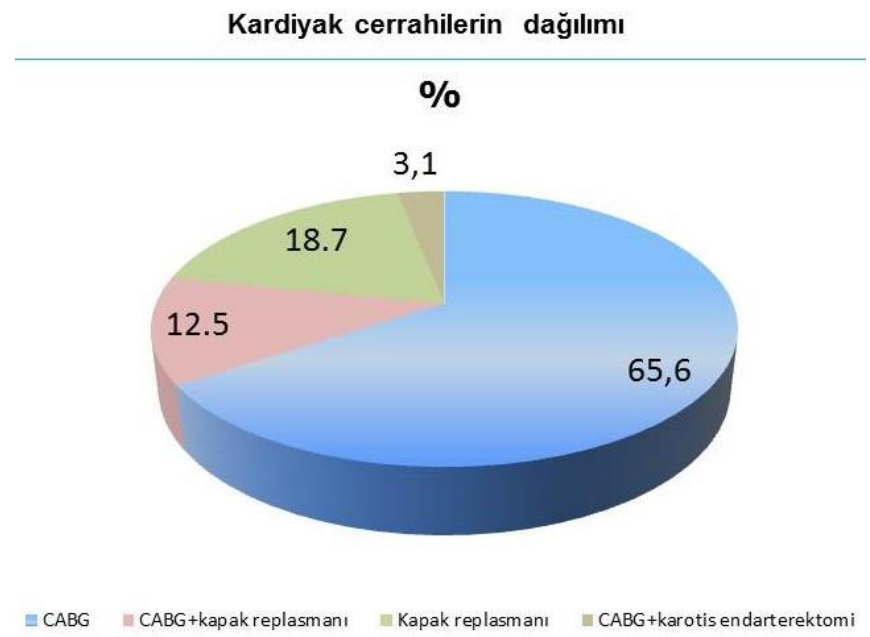

Şekil 1: Kardiyak cerrahilerin dağılımı.

Sağlık bakımı ile ilişkili enfeksiyon gelişen olguların \%71,9 (23)'u erkek, ortalama yaşları 62.2 (38-80) ve\%68,8 (22)'inin ASA skoru $\geq 3$ idi. Ortalama VKİ 24,8, 11'i \%34,4 (11)'ü obez hastalardan oluşmaktaydı. Yirmi yedi $(\% 84,3)$ hastada en az bir komorbidite vardı. Sıklık sırasına göre eșlik eden preoperatifkomorbiditeler; \%43,7 (14) diyabet, $\% 31,2$ (10) hipertansiyon, \%21,8 (7) hiperlipidemi, \%6,2 (2) kronik obstruktif akciğer hastalığı, \%3,1 (1) kronik böbrek hastalığı, \%3,1 (1) hipertiroidi (ameliyat sırasında ötiroid) idi. Hastaların \%28,1'i sigara içicisi olup, bir kişi dışında alkol kullanımı yoktu. Burun kültürü alınan 17 hastanın ikisinde metisiline duyarlı S. aureus (MSSA) taşıyıcılığl saptanarak ve dekolonizasyon tedavisi verildi. SBİE gelişen hastaların ortalama yatış süresi $32.7 \pm 26.6$ gün ve ameliyat süresi; $397 \pm 130.2$ dakika $(180-780 \mathrm{dk})$ idi.
Sağlık bakımı ile ilișkili enfeksiyon gelișen hastaların operatif ve demografik özellikleri Tablo 1'de, risk faktörlerinin değerlendirmesi ise Tablo 2'de özetlendi.

Tablo 1: SBİE gelişen kardiyak cerrahi hastalarının operatif ve demografik özellikleri.

\begin{tabular}{|c|c|}
\hline $\begin{array}{l}\text { SBIE gelișen kardiyak cerrahi } \\
\text { hastalarının operatif ve } \\
\text { demografik özellikleri }\end{array}$ & Sayı \\
\hline Erkekcinsiyet & $23(\% 71,9)$ \\
\hline Ortalama yaş; (min-max) / $\geq 65$ yaş & $\begin{array}{l}62,2 ;(38-80) / 17 \\
(\% 53,1)\end{array}$ \\
\hline Vücut kitle indeksi (VKİ)- ortalama & 24,8 \\
\hline Yatış süresi \pm SD (min-max) gün & $32.7 \pm 26.6(6-120)$ \\
\hline $\begin{array}{l}\text { Ameliyat süresi } \pm \text { SD (min-max) } \\
\text { dakika }\end{array}$ & $397 \pm 130.2(180-780)$ \\
\hline Pompa süresi \pm SD (min-max) dakika & $157.5 \pm 98.1(73-425)$ \\
\hline Ameliyat tipi; Acil /Elektif & $2(\% 6,2) / 30(\% 93,7)$ \\
\hline Önceden kardiyak cerrahi geçirenler & $3(\% 9,3)$ \\
\hline $\begin{array}{l}\text { SBİE belirlendiği ortalama gün } \\
\text { sayısı } \pm \text { SD }\end{array}$ & $20.9 \pm 20,7$ \\
\hline $\begin{array}{l}\text { Mortalite / enfeksiyon ilişkili } \\
\text { mortalite }\end{array}$ & $9(\% 28,1) / 7(\% 21,8)$ \\
\hline Mortalitesüresi \pm SD & $49.8 \pm 41(7-120)$ \\
\hline
\end{tabular}

Enfeksiyonların dağılımı sırası ile; \%61,1 (22/36)'i cerrahi alan enfeksiyonu (CAE), $\% 24,9$ (9/36)'u pnömoni, \%8,2 (3/36)'si kan dolaşımı enfeksiyonu, \%5,5 (2/36)'i idrar yolu enfeksiyonu idi.Cerrahi alan enfeksiyonlarının 11'i yüzeyel, 7'si organ boşluk ve 4'ü derindi. Pnömonilerin ve kan dolaşımı enfeksiyonlarının biri invazif araç ilişkili iken, idrar yolu enfeksiyonlarının tamamı kateter ile ilişkiliydi. Sağlık bakımı ile ilișkili enfeksiyonların $\quad \% 77,8 \quad(28 / 36)$ 'inde etyolojiden sorumlu mikroorganizmalar izole edilebildi ve en baskın etken; \%55,6 (20/36) ile gram negatif mikroorganizmalar idi. Çoklu ilaç direnci olan mikroorganizmalar \%36,1(13/32) ve genişletilmiş ilaç direnci olan 
mikroorganizmalar $\% 2,1(1 / 32) \quad$ oranında bulundu. SBİE'larda etken bakterilerin dağılım oranları Şekil 2'te gösterildi.

Tablo 2: Kardiyak cerrahi hastalarında sağlık bakımı ile ilişsili risk faktörleri.

\begin{tabular}{|c|c|}
\hline $\begin{array}{l}\text { Kardiyak cerrahi hastalarında SBİE'ın } \\
\text { risk faktörleri }\end{array}$ & $\begin{array}{c}\text { Hasta sayısı(n:32), SBIE } \\
\text { sayısı (n:36) } \\
\end{array}$ \\
\hline Komorbidite / DM & $27(\% 84,3) / 14(\% 43,7)$ \\
\hline Sigara/alkol & $9(\% 28,1) / 1(\% 3,1)$ \\
\hline Operasyon öncesi yatış süresi $\geq 3$ gün & $12(\% 37,5)$ \\
\hline $\begin{array}{l}\text { Sefazolinprofilaksisi }>72 \text { saat } \\
48-72 \text { saat } \\
\leq 24 \text { saat }\end{array}$ & $\begin{array}{c}5(\% 15,6) \\
19(\% 59,3) \\
8(\% 25) \\
\end{array}$ \\
\hline $\begin{array}{l}\text { Internalmammarian arter (IMA) kullanımı / } \\
\text { Bilateralinternalmammarianarter (BIMA) } \\
\text { kullanımı }\end{array}$ & $28(\% 75) / 7(\% 21,9)$ \\
\hline $\begin{array}{l}\text { Ameliyat sırasında transfüzyon / masif } \\
\text { transfüzyon }\end{array}$ & $28(\% 87,5) / 3(\% 9,3)$ \\
\hline $\begin{array}{l}\text { Ameliyat süresi > } 300 \mathrm{dk} / \text { pompa süresi } \\
>180 \mathrm{dk}\end{array}$ & $26(\% 81,3) / 11(\% 34,1)$ \\
\hline $\begin{array}{l}\text { Kanamaya bağlı revizyon cerrahisi / intra- } \\
\text { aortik balon pompası/ sternumun geç } \\
\text { kapatılması }\end{array}$ & $\begin{array}{c}4(\% 12,5) / 3(\% 9,3) / 4 \\
(\% 12,5)\end{array}$ \\
\hline $\begin{array}{l}\text { Ameliyat sonrasıkan glukoz düzeyi } \geq 200 \\
\text { mg/dl }\end{array}$ & $14(\% 43,8)$ \\
\hline Mekanik ventilasyon süresi > 24 saat & $14(\% 43,8)$ \\
\hline Re-entübasyon & $5(\% 15,6)$ \\
\hline Ameliyat sonrasıiskemik inme gelişen hasta & $6(\% 18,7)$ \\
\hline $\begin{array}{l}\text { Ameliyatsonrası renalreplasman tedavisi } \\
\text { ihtiyacı }\end{array}$ & $6(\% 18,8)$ \\
\hline
\end{tabular}

Klinik takipte hastaların 9'unda mortalite gelişti. Bunların 7'si enfeksiyonla ilişkiliydi.

Mortalite gelişen olguların yoğun bakım ünitesindeki ortalama yatış süresi 35 (3-120) gündü. Bu olguların büyük çoğunluğu (7/9) enfeksiyon ve/veya kardiyak bir komplikasyon sonucu yoğun bakım ünitesinden servis takibine çıkartılamamış olan hastalar iken, yaşayan olguların \%87 (20/23)'sinin yoğun bakım ünitesindeki yatış süresi dört günden kısa idi.

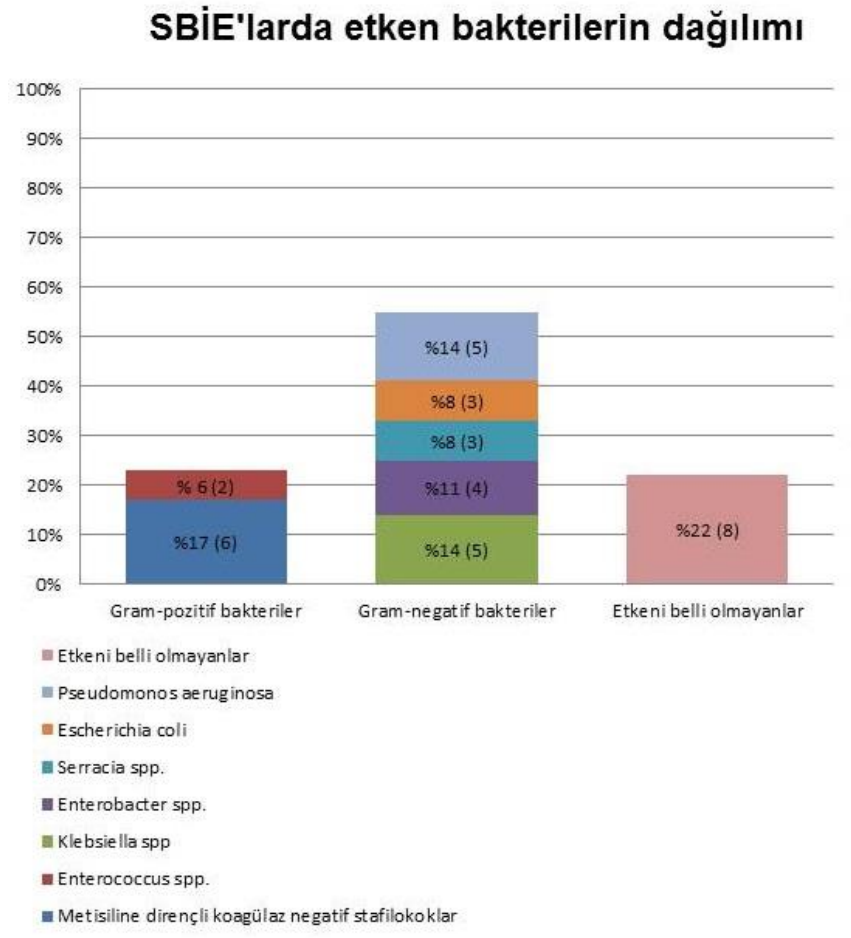

Şekil 2:SBíE’larda etken bakterilerin dağılımı.

\section{TARTIŞMA}

Kardiyak cerrahi sonrası gelişen majorenfeksiyonlarınmortaliteyi beş kat

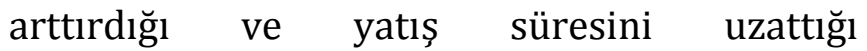
gösterilmiştir ve bu hastalarda SBİE'ların gelişimini artıran risk faktörleri oldukça fazladır ${ }^{11} . \mathrm{Bu}$ faktörler arasında; ileri yaş, yüksek ASA skoru, diyabet, obezite S. aureuskolonizasyonu, cerrahi profilaksi metodolojisi, uzayan ameliyat süresi, kan transfüzyonu, İMA kullanımı, revizyon cerrahisi, hiperglisemi, postoperatif dönemde çok sayıda invazif araç kullanımı (santral venözkateter, üriner sonda, intra-aortik balon..) ve "by-pass" cerrahisi için birden çok cerrahi insizyon alanı olması olaraksayılabilir ${ }^{3,4,8,11}$.

Çalışmamızda altı yıllık süreçte ortalama SBİE gelişme hızı \%4,8 (36/744) olarak saptandı. Literatürde bildirilen oranlar \%2,25-24.9 iken, ülkemizden yapılan yayınlarda ise bu oran \%2,9-9.3 arasında değişmekte idi. Son yıllarda yapılan prospektif çalışmalarda ise bu oran 
\%10'dan daha fazla bildirilmektedir ${ }^{1,3,6,12,13,14,15}$. olarak Enfeksiyon oranlarının geniş bir yelpazede dağılması; çalışmaların birçoğunun retrospektif özellikte olması, SBİE tanımlarındaki standardizasyon eksikliği, taburculuk sonrası surveyanstaki yetersizlikler ve hasta gruplarının standardizasyonunun olmaması ile ilişkilendirilmiştir ${ }^{14,16}$. Bizim çalışmamızdaki SBIE'ların hızı bildirilen oranların daha altındadır. $\mathrm{Bu}$ sonuç; gerek çalışmamızın retrospektif olması, gerek hasta volümünun az olduğu merkezimizde izolasyon, el hijyenine uyum ve invazif araç ilişkili enfeksiyonlardan korunmada kontrol demetlerinin efektif uygulanması ve surveyans verilerinin geri bildirimi ile ilgili olduğu düşünüldü.

Literatürde kardiyak cerrahi sonrası görülen SBİE'lar arasında en sık (\%32,9-52,6) rastlanan enfeksiyon türü genellikle CAE'larıdır ve hızı \%2-10 arasındadır ${ }^{1,3,4,6,12,17,18}$. Cerrahi alan enfeksiyonları artmış morbidite, mortalite, uzayan hastane yatışı ve artan maliyet ile beraber istenmeyen komplikasyonlardandır ${ }^{19-}$ 21. Bizim çalıșmamızda en sık karșılașılan SBIEE türü CAE oranı \%61,1 olup, altı yıllık ortalama hızı $\% 2,9$ olarak saptandı.

Uzayan ameliyat süresi ( $>5$ saat)CAE riskini arttırmakta ve cerrahi alanın kontamine olma olasılığının artmasına yol açmaktadır. Ayrıca uzayan operasyonlar büyük çapta ve daha komplike girişimler olup, bu durum CAE riskinin artışına ayrıca katkıda bulunmaktadır ${ }^{14}$. Çalışmamızda SBİE gelişen olguların \%81,3 (26)'ünde ameliyat süresi beş saatin üzerindeydi ve bu olguların da 19'unda gelişen enfeksiyon türü CAE idi.

Diğer önemli risk faktörlerinden olan obezite ve diyabet ise SBİE'ların gelişme riskini artıran diğer komorbiditelerdir. Obezite; akciğer kapasitesinde azalma, hiperglisemi, mobilize olamama ve zorlaşan cerrahi teknik nedeni ile uzayan ameliyat süresi gibi nedenlerden dolayı SBİE’ların gelişimini artıran bir etkendir ${ }^{22,23}$.
Çalışmamızda SBİE gelişen hastalarımızın \%34,4'ü (11/32) obez hastalardan oluşmakta olup, bunlarm \%90,9 (10/11)'unda CAE gelişmişti. Diyabet ise; lökosit fonksiyonlarında bozulma, yara iyileşmesinde gecikme nedeni ile enfeksiyona risk teşkil etmektedir ${ }^{24}$ Olgularımızın \%43,7 (14/32)'si diyabetik idi. Tüm olgular ameliyat öncesi-sırasında ve sonrasındaki dönemde optimal kan glukozu regülasyonu açısından endokrinoloji uzmanı tarafından değerlendirilerek tedavileri düzenlendi. Ancak ameliyat sonrası dönemde sıkı kan glukoz takibine rağmen optimal regülasyon sağlanamadı ve hiperglisemik seyrettikleri görüldü. Bunların \%78,6 (11)'sında CAE geliști ve yine bu hasta grubunda literatürdeki çalışmaların aksine etyolojide gram negatif mikroorganizmalarm predominansı $(\% 57,1)$ saptandı. Güncel çalışmalarda kardiyak cerrahi sonrası CAE'larında gram negatif bakterilerin \%21,7-35 oranında etken olduğu bildirilmiş iken çalışmamızı destekleyen veri ülkemizde yapılmış yayınlardan Taş ve arkadaşlarının yaptığı bir çalıșma sonuçlarından gelmiştir ${ }^{25-}$ 27.Nitekim bu çalışmada preoperatif ve postoperatif dönemde iyi regüle edilmeyen kan glukoz düzeylerinin yara yeri enfeksiyonu açısından önemli bir risk faktörü olduğu vurgulanmış ve çalışmamızda da olduğu gibi diyabetik hastalarda yara yeri enfeksiyonunda gram negatif mikroorganizmaların önde gelen etken olduğu saptanmıştır ${ }^{27}$. Artan diyabet prevelansı ve bu hastalar için uygulanan kardiyak cerrahi girişimlerin artış hızı göz önüne alındığında bizim verilerimizi destekleyecek yeni yayınlar bu konudaki literatüre ışık tutacaktır.

Çok sayıda gözlemsel çalışmada; kardiyak cerrahide İMA kullanımı altın standart olarak tanımlanmış ve safenven kullanımına göre;yaşam süresini, geç miyokardinfarktüsü riskini, tekrarlayıcı anginayl ve revaskülarizasyon ihtiyacını azalttığı gösterilmiștir ${ }^{28}$. Ancak bu arterin by-pass 
cerrahisinde kullanımı ile sternumun kanlanmasının bozulduğu ve CAE gelişiminde risk faktörü olduğu da bildirilmiştir ${ }^{21,29}$. Çalışmamızda kardiyak cerrahi uygulanan tüm olgularımızda İMA kullanıldı ve gelişen SBIE'ların \%61,1 (22/36)'i CAE idi.

Kardiyak cerrahide kan ve kan ürünleri sıklıkla kullanılmaktadır. Çok merkezli ve 5158 kardiyak cerrahi olgunun dahil edildiği gözlemsel, prospektif bir çalışmada; intraoperatif ve/veya postoperatif eritrosit transfüzyonu yapılan olgularda her bir ünite eritrosit transfüzyonunun majorenfeksiyon riskini artırdığı saptanmıştır ${ }^{30}$. Bizim çalışmamızda da intraoperatif olarak \%87,5 (28/32) oranında eritrosit ve/veya diğer kan ürünlerini kullandığı belirlendi.Üç hastaya masif transfüzyon uygulanmış olup bu hastaların tamamı kaybedildi.

Uzayan mekanik ventilasyon süresinin ( $>24$ saat) SBİE riskini ve mortaliteyi artırdığ yapılan çalışmalarda gösterilmiş olup, SBİE gelişen olgularımızın \%43,8 (14)'inde uzayan mekanik ventilasyon süresi belirlendi11,31 .

Kardiyak cerrahi sonrası SBİE türleri arasında pnömoniler ikinci sıklıkta (\%25) kan dolaşımı enfeksiyonları\%5,8-30 oranı ile üçüncü sıklıkla ve idrar yolu enfeksiyonları ise daha az sıklıkla \%4,1-19.2 bildirilmektedir 1,4,12,17. Bizim çalışmamızda da benzer çalışmalarla uyumlu olarak; pnömoniler \%25, kan dolaşımı enfeksiyonları \%8,3, idrar yolu enfeksiyonu $\% 5,5$ oranında saptand $1^{12,14}$.

Kardiyak cerrahi sonrası gelişen enfeksiyonlarda etyolojide rol oynayan mikroorganizmalar ilgili merkezin vaka volümü, enfeksiyon kontrol önlemleri ve hastaların komorbiteleri gibi faktörlere bağlı olarak farklılık gösterebilmekle beraber çalışmalarda gram pozitif bakterilerin predominansı olduğu da görülmektedir ${ }^{3,26}$. Bizim çalışmamızda gelişen 36 enfeksiyonda $\% 55,5$ oranında (20/36) gram negatif bakterilerin önde gelen etken olduğu saptandı.
$\% 22,2$ (8/36)'sinde ise gram pozitif bakterilerin etken olduğu görüldü. Sekiz $(\% 22,2)$ enfeksiyonda ise sorumlu mikroorganizma üretilemedi (Tablo 3).

Çalışmamızda SBİE gelişen olgularda gelişen $\% 28,1$ oranındaki mortalite literatürle uyumludur 3,5,13,26. Tablo 2'de belirtilen çoğu risk faktörü (komorbidite, İMA kullanımı, ameliyat sirasinda transfüzyon, uzayan ameliyat süresi, post-operatifhiperglisemik seyir, uzayan mekanik ventilasyon süresi) mortalitenin önde gelen nedenleri arasında olup, yoğun bakım ünitesinde dört günden uzun yatış süresi olan hastalarda mortalitenin daha yüksek olması da [ \%72,7 (8/11) ] dikkat çeken bir diğer noktadır.

Sonuç olarak; çalışmamızda tek merkezin kalp ameliyatları sonrasında gelișen SBİE oranlarını paylaştık. Retrospektif, olgu sayısının azlığı, kontrol grubunun olmaması çalışmamızın sınırlayıcıları olarak belirlenebilir. Yukarıda da detaylı olarak belirttiğimiz gibi SBİE'ların gelişimi açısından en temel risk faktörleri; ileri yaș, yüksek ASA skoru, diyabet, obezite, İMA kullanımı, uzayan ameliyat süresi, intraoperatif kan ve kan ürünü kullanımı, postoperatifhiperglisemik seyir, uzayan mekanik ventilasyon süresidir ve literatürdeki büyük volümlü çalışma sonuçları da bizim sonuçlarımızı desteklemektedir.

Teşekkür; Hastaların takip ve tedavi sürecinde eşsiz destek ve yardımları olan Prof. Dr. Ahmet Özkara, Uzm. Dr. Halil Hüzmeli, Prof. Prof. Dr. Didem Dal, Prof. Dr. Simru Tuğrul ve Uzm. Dr. Ahmet Başel'e, başarılı enfeksiyon kontrolü ve surveyans çalışmaları için Yeşim Koçak'a ve çok değerli önerileri ile katkıda bulunan Prof. Dr. Binnur Şimşek'e teşekkür ederiz.

Çıkar Çatışması Beyanı: Yazarlar çıkar çatışması olmadığını bildirmişlerdir.

Finansal Destek: Bu çalışma her hangi bir fon tarafından desteklenmemiştir. 
Declaration of Conflicting Interests: The authors declare that they have no conflict of interest.

Financial Disclosure: No financial support was received.

\section{KAYNAKLAR}

1. Lola I, Levidiotou S, Petrou A, Arnaoutoglou H, Apostolakis E, Papadopoulos GS. Are there in dependent predisposing factors for post operative infections following open heart surgery?. J Cardiothorac Surg. 2011; 6: 151.

2. Davoudi A, Najafi N, Alian S,et all. Resistancepattern of antibiotics in patient under wentopen heart surgery with nosocomial infection in north of Iran. Glob J Health Sci. 2015; 8: 288-97.

3. De Santo LS, Bancone C, Santarpino G,et all. Microbiologically documented nosocomial infection saftercardiac surgery: an 18-month prospective tertiarycarecentrereport. Eur J CardiothoracSurg. 2008; 33: 666-72.

4. Andrioli ER,Cavalheiro RA,Furtado GC, Gomes WJ,Medeiros EA. Healthcare-associated infections in the post operative period after cardiac surgery.Int J Infect Control 2018; 14: 1-10

5. Sahu MK, Siddharth B, Choudhury A, et all.Incidence, microbiological profile of nosocomial infections, and the irantibiotic resistancepatterns in a high volume cardiacsurgical intensive careunit. Ann Card Anaesth. 2016; 19: 281-7.

6. Heydarpour F, Rahmani Y, Heydarpour B, Asadmobini A. Nosocomial infectionsand antibiotic resistancepattern in open-heart surgery patients at Imam Ali Hospital in Kermanshah, Iran. GMS HygInfect Control. 2017; 12: Doc07.

7. O'Keefe S, Williams K, Legare JF. Hospital-acquired infections after aardiac surgery and current physicianpractices: a retro spectivecohortstudy.J Clin MedRes. 2017; 9: 10-6.

8. Şimşek Yavuz S. Kardiyoloji ve kardiyak cerrahi ünitelerinde görülen hastane enfeksiyonları. Hastane İnfeksiyonları Dergisi 2003; 7: 168-88.

9. Horan TC, Andrus M, Dudeck MA. CDC/NHSN Surveillance Definition of Healthcare-Associated Infection and Criteria for Specific Types of Infections in the Acute Care Setting.Am J Infect Control 2008; 36: 309-32.
10. Magiorakos AP, Srinivasan A, Carey RB, et all. Multidrug-resistant, extensivelydrug resistant and pandrug-resistantbacteria: An international expert proposalforinterim Standard definitions for acquiredresistance. Clin Microbiol Infect. 2012; 18: 268-81.

11. Cove ME, Spelman DW, MacLaren G. Infectiouscomplications of cardiac surgery: a clinical review. J Cardiothorac Vasc Anesth. 2012; 26: 1094100

12. Davoudi A, Najafi N, Alian S, et all.ResistancePattern of Antibiotics in Patient Underwent Open Heart Surgery With Nosocomial Infection in North of Iran. Glob J HealthSci. 2015; 8: 288-97.

13. Coşkun D, Aytaç J.Kardiyovasküler cerrahi sonrası gelişen nozokomiyal enfeksiyonların değerlendirilmesi. Anatol J Cardiol. 2007; 7: 164-68.

14. Şimşek-Yavuz S,Biçer Y, Yapıcı N ve ark. Kardiyak cerrahi ameliyatlardan sonra gelișen hastane enfeksiyonlarl: sürveyans ve risk faktörlerinin analizi. Klimik Dergisi. 2005; 18: 103-10.

15. Göl MK, Karahan M, Ulus AT, et all. Bloodstream, respiratory, and deep surgicalwoundinfections after open hearts urgery. J CardSurg. 1998; 13: 252-9.

16. Figuerola-Tejerina A, Rodríguez-Caravaca G, Bustamante-Munguira J, María San Román-Montero J, Durán-Poveda M. Epidemiologicalsurveillance of surgical site infection and its risk factors in cardiac surgery: a prospective cohortstudy. Rev Esp Cardiol (EnglEd). 2016; 69: 842-8.

17. Rebollo MH, Bernal JM, Llorca J, Rabasa JM, Revuelta JM. Nosocomialinfections in patients having cardio vascular operations: a multivariate analysis of risk factors. J Thorac Cardiovasc Surg. 1996; 112: 908-13.

18. Musallam E. Thepredictors of surgical site infection post cardiacsurgery: a systematic review. J VascNurs. 2014; 32: 105-18.

19. Kirkland KB, Bridges JP, Trivette SL, Wilkinson WE, Sexton DJ.Theimpact of surgical site infections in the 1990: attributablemortality, excesslength of hospitali zationandextracosts. Infect Control Hosp Epidemiol 1999; 20: 725-30.

20. Cristofolini M, Worlitzsch D, Wienke A, Silber RE, Borneff-Lipp M.Surgical site infections after coronaryartery bypass graftsurgery: incidence, perioperative hospitalstay, readmissions, and revision surgeries. Infection. 2012; 40: 397-40. 
21. Lepelletier D, Perron S, Bizouarn P,et all. Surgical-site infection after cardiac surgery: incidence, microbiology, and risk factors. Infect Control HospEpidemiol. 2005; 26: 466-72.

22. Yap $\mathrm{CH}$, Mohajeri M, Yii M. Obesityandearlycomplications after cardiac surgery. Med J Aust. 2007; 186: 350-4.

23. Huttunen $R$, Karppelin $M$, Syrjänen J.Obesityandnosocomia linfections. J HospInfect. 2013; 85: 8-16.

24. Casqueiro J, Casqueiro J, Alves C. Infections in patients with diabetes mellitus: A review of pathogenesis. Indian J Endocrinol Metab. 2012;16 Suppl 1: S27-36.

25. Kotnis-Gąska A, Mazur P, Olechowska-Jarząb A, et all. Sternalwound infections following cardiac surgery and their management: a single-centrestudy from the years 2016-2017. Kardiochir TorakochirurgiaPol. 2018; 15: 79-85.

26. Michalopoulos A, Geroulanos S, Rosmarakis ES, Falagas ME. Frequency, characteristics, andpredictors of microbiologically documented nosocomial infections after cardiac surgery. Eur J CardiothoracSurg. 2006; 29: 456-60.
27. Taş S, Yazıcı D,Antal Dönmez A, ve ark.Açık kalp cerrahisi hastalarında diyabet ve kan glukozu kontrolünün cerrahi alan enfeksiyonları üzerine etkisi. Kosuyolu Kalp Derg. 2013; 16: 199-204.

28. Sajja LR. Strategiestoreducedeepsternalwound infection after bilateralinternalmammaryartery grafting. Int J Surg. 2015; 16(Pt B): 171-8.

29. Pick AW, Orszulak TA, Anderson BJ, Schaff HV. Single versusbilateralinternalmammaryartery grafts: 10 -year outco meanalysis. AnnThoracSurg. 1997; 64: 599-605.

30. Horvath KA, Acker MA, Chang $\mathrm{H}$, et all.Blood transfusionandinfectionaftercardiacsurgery. AnnThoracSurg. 2013; 95: 2194-201.

31. Gelijns AC, Moskowitz AJ, Acker MA, et all. Management practicesandmajorinfections after cardiac surgery. J Am Coll Cardiol. 2014; 64: 372-81. 